\title{
Are the Enrichment Nutrient Feasible to the Vermicomposting Efficiency For Water Hyacinth (E. Crassipes)?
}

Karolina Kotsubo ( $\sim$ karol.kotsubo@gmail.com )

UFSCar: Universidade Federal de Sao Carlos https://orcid.org/0000-0002-2996-057X

Irineu Bianchini Júnior

UFSCAR

Marcela Bianchessi da Cunha Santino

UFSCAR

Hugo Henrique Lanzi Saulino

UFSCAR

\section{Research}

Keywords: Eisenia fetida, priming effect, eutrophication, humification, sustainability

Posted Date: July 30th, 2021

DOl: https://doi.org/10.21203/rs.3.rs-751454/v1

License: (a) (1) This work is licensed under a Creative Commons Attribution 4.0 International License.

Read Full License 
Are the enrichment nutrient feasible to the vermicomposting efficiency for water hyacinth (E. crassipes)?

Karolina Kotsubo ${ }^{1} *$

Irineu Bianchini Jr. ${ }^{1,2}$

Marcela Bianchessi da Cunha-Santino ${ }^{1,2}$

Hugo Henrique Lanzi Saulino ${ }^{1}$

*karol.kotsubo@gmail.com (corresponding author)

${ }^{1}$ Programa de Pós-Graduação em Ecologia e Recursos Naturais, Universidade Federal de São Carlos. Rodovia Washington Luiz, 235 km - SP-310, CEP: 13565-905, São Carlos, SP, Brasil.

${ }^{2}$ Laboratório de Bioensaios e Modelagem Matemática, Departamento de Hidrobiologia, Universidade Federal de São Carlos. Rodovia Washington Luiz, 235 km - SP-310, CEP: 13565-905, São Carlos, SP, Brasil. 


\begin{abstract}
In eutrophic environments, aquatic weeds reproduce quickly and occupy large areas, preventing multiple uses of water resources. The use of the biomass of these plants in vermicomposting represents a sustainable alternative. The enrichment of macrophyte biomass during vermicomposting was tested using inorganic NPK solution (1.75\% and $3.5 \%)$ and organic solution $(0.25 \mathrm{~g} / \mathrm{L}$ and $0.5 \mathrm{~g} / \mathrm{L})$ to improve the quality of the compound. Biomass consumption increased as the experiment progressed, reaching the highest values at the end. The experiment without worms remained stable. The influence of $E$. fetida individuals the vermicomposting process of water hyacinth will depend nutrient addition. The additions improved subtly the compost quality and the consumption of biomass, besides its low-cost, easily obtained and applicable treatment. It does not have the necessary requirements for its use as a fertilizer. However, we suggest the use in association with other fertilizers, adding moisture and structuring to the soil.
\end{abstract}

Keywords: Eisenia fetida, priming effect, eutrophication, humification, sustainability

\title{
1. Introduction
}

Macrophytes are aquatic plants that colonized both aquatic environments and transitional with terrestrial ones (Chambers et al., 2008) with great plasticity and adaptability (Najar, 2017), offering a variety of ecosystem services (e.g., refuge for species, food and habitat) (Bento et al., 2007). The reproductive characteristics of this group are greater in eutrophic environments resulting in population explosions with the formation of vegetation mats, which promotes losses of multiple uses of water resources, causing several negative ecological and socioeconomic impacts (Villamagna 
\& Murphy, 2010; Chapungu et al., 2018; Zhang et al., 2019). Among the floating macrophytes that normally occur in eutrophic freshwater bodies, it stands the aquatic weed water hyacinth Eichhornia crassipes (Martius) Solms-Laubach (Pontederiaceae). This species is originally from South America with widespread invasive potential (Howard \& Harley, 1997; Koutika \& Rainey, 2015; Kurugundla et al., 2016; Cordeiro et al., 2020).

Due the high biomass production in eutrophic systems, the use of macrophyte biomass represents an ecological and sustainable alternative economic use of these vegetables. One of the main characteristics of the treatment is the possibility of using practically any organic material and the formation of a nutritious compound that can be used for fertilization. It is justify especially once weed water hyacinth as a source of macronutrients as nitrogen, phosphorus and potassium which improve the soil fertility (Kumari et al., 2021) However, there are few sustainable techniques applied, such as physical, chemical and biological methods that have undesirable impacts (e.g. contamination by herbicides) (Thomaz, 2002). The use of excess biomass as a raw material for vermicomposting thus consists of a possibility of reducing an environmental problem by applying this biomass in sustainable techniques (Najar, 2017). Composting consists in a treatment of waste regulated by microbial decomposition, featured by the oxidation of organic matter. A process similar to composting is vermicomposting, which is distinguished by the use of mesofauna, especially Eisenia fetida (Oligochaeta, Lumbricidae). The process of composting is facilitate by the combined action of earthworms with that of flora present in your digestive tract. During composting, part of the organic matter is mineralized in carbon dioxide, ammonia and water, while the other part is transformed into humic substances (Valente et al., 2009). Hamer (2004) observed that the positive effects of adding 
different organic substrates are often related on the mineralization of organic carbon in the soil. Blagodatskaya et al. (2007) indicated that the addition of carbon-rich compounds can strongly change the turnover of native organic matter, causing the priming effect. As stated by Tótola \& Chaer (2002), a high-quality soil has intense biological activity that can be defined by microbiological indicators, therefore, the priming effect is beneficial to the mineralization process and increased soil quality.

Addition of exogenous organic matter in the soil can cause intensification or delay in the decomposition of organic matter (Chen et al., 2014). Decomposition requires a sequential breakdown of a variety of substrates (such as: waxes, phenols, lignin, and cellulose). The priming effect overcomes this limitation by availability of more nutrients from fresh organic matter. Kaspari et al. (2008) exemplifies this statement when describing the decomposition of litter, in which the decomposing microorganisms are presented as the main limiting factors. In that case, the provision of a greater amount of nutrients would accelerate this process since enzymes produced by different microbes are required. Laskowski \& Berg (2005) showed that nitrogen-rich leaves decompose more quickly when compared to nitrogen-poor leaves. Incorporation of inorganic and organic elements as an additional source of nutrients for priming effect may improve the quality of the vermicompost generated by macrophyte biomass. This addition can be exemplified in similar studies by adding additional sources of nutritious organic compounds in studies such as animal waste. It is common to add manure to vermicomposting of macrophytes, mainly from cattle (Gajalashmi et al., 2000; Gajalashmi et al., 2002; Najar \& Khan, 2013; Bernal et al., 2016; Suthar et al., 2016; Devi \& Khwairakpam, 2020). This mixture is favorable to the adaptation of earthworms and beneficial for improving the consumption of macrophyte biomass by them. In a comparative experience, Bernal et al. (2016) vermicomposted E. crassipes, cattle 
manure in a combined treatment of both in the proportion of $50 \%$. The experiment achieved total conversion of macrophyte biomass in 110 days. Ansari \& Rajpersaud (2012) vermicomposted E. crassipes with organic waste of grass clippings, and combined experiment of both. Vermicompost with E. crassipes had a conversion rate of $56.14 \%$ while the combined treatment obtained a conversion rate of $76.19 \%$.

This study aimed to study vermicomposting using the biomass of Eichhornia crassipes as a source of organic matter, aiming to evaluate the compound generated after the addition of organic and inorganic substance (glucose and commercial fertilizer NPK) in two concentrations each. The specific objectives were: (i) to evaluate the kinetics of macrophyte consumption by E. fetida; (ii) evaluate the quality of the humus formed from the vermicomposting by means of particles; (iii) identify whether the addition of a pre-activator (organic and inorganic) will increase the quality of the generated humus and (iv) evaluate the consumption of macrophyte biomass by E. fetida using mathematical modeling. This study had the hypothesis that the incorporation of both substances as an additional source of nutrients may improve the quality of the vermicompost generated in the macrophyte biomass by priming effect.

\section{Methods}

\subsection{Assembly and preparation of vermicomposting experiment}

Specimens of water hyacinth were collected manually at the Departmento de Botânica (DB) of the Universidade Federal de São Carlos (UFSCar). After collected, the macrophytes were manually washed in running water to remove aggregate debris. All parts of the plant were used, which were cut after this process to facilitate the consumption. A portion of the specimens were kiln dried (ca. $50^{\circ} \mathrm{C}$ ) until constant 
mass. This procedure allowed composing the proportions of biomass (dry and fresh $3: 1)$.

The vermicomposting experiment occurred in three dark polypropylene boxes, previously cleaned, dried and stacked (total dimension: $32 \mathrm{~cm}$ long, $16 \mathrm{~cm}$ wide and 36 cm high). The system were composed of two digester boxes (total volume: $8 \mathrm{~L}$ ) and a collection box (volume: $4 \mathrm{~L}$ ). In the digester boxes a layer of ca. $2 \mathrm{~cm}$ of an inert substrate was set. This substrate consisted of a mixture of vermiculite and sand (1:1 ratio). Above the substrate, a polypropylene mesh $($ mesh: $1 \mathrm{~cm})$ was placed for separation between the inert substrate and the macrophyte biomass. This procedure aimed to facilitate the final separation of the remaining macrophyte biomass after the end of the vermicomposting and, thus, to calculate the consumption efficiency of the water hyacinth biomass. Thirty specimens of Eisenia fetida (Oligochaeta, Lumbricidae) with varying sizes and masses were selected, contemplating all stages of life of the species. The individuals had their length (in $\mathrm{cm}$ ) determined before and after each treatment using a millimeter rule. The initial and final biomasses of the specimens were determined on a precision scale (brand Bel Engineering, model M214Ai; precision $0.0001 \mathrm{~g}$ ) and the number of individuals was counted at the beginning and after the end of the vermicomposting. Before the beginning of vermicomposting $(\mathrm{n}=3$ for each treatment), 30 individuals of E. fetida were kept in the digestion boxes for $24 \mathrm{~h}$ for adaptation. Some standards must be followed so the vermicomposting reaches its objectives and, at the same time, corresponds to the tolerance standard of the present macrofauna. Therefore, it was sought to keep earthworms at $25^{\circ} \mathrm{C}$ and $75 \%$ humidity (Venter \& Reinecke, 1988). The added macrophytes must be in both fresh and dry form, with the addition of $10 \mathrm{~g}$ of fresh biomass and $30 \mathrm{~g}$ of dry biomass. 
At the same time, mini systems $(n=24$ for each treatment) were set up to observe the consumption kinetics of macrophyte biomass. The mini systems were prepared with E. crassipes biomass and E. fetida individuals in the same proportion as the previously described in the system ( $1 \mathrm{~g}$ of fresh biomass, $3 \mathrm{~g}$ of dry biomass and 3 individuals of E. fetida). The mini system were dismounted weekly (following the same procedures described) and the consumption efficiency of E. crassipes biomass was calculated (Equation 1).

$$
E=\frac{B_{e}-B_{S}}{B_{e}} \times 100
$$

where: $\mathrm{E}=$ consumption efficiency $(\%) ; \mathrm{Be}=$ input biomass; $\mathrm{Bs}=$ outgoing biomass.

Experiments without earthworms $(n=24)$ and without treatment were also set up to allow a comparison between the consumption of biomass by the annelids and the microorganisms. This experiment was done in the same proportions as the mini systems, but without E. fetida individuals.

The treatments contemplating the addition of nutrients were conducted by the application of commercial inorganic fertilizer (Casa Verde, foliar solution), containing nitrogen, phosphorus, and potassium (NPK) in the proportion 15-05-05 and the organic aquatic solution of glucose $\left(\mathrm{C}_{6} \mathrm{H}_{12} \mathrm{O}_{6}\right)$. The commercial fertilizer used was added as aqueous solution, in the concentrations $1.75 \%$ and $3.5 \%$. The organic solution of glucose was added in the concentrations $0.25 \mathrm{~g} / \mathrm{L} \mathrm{e} 0.5 \mathrm{~g} / \mathrm{L}$. Both solutions were used as a way to maintain the humidity in the earthworms during the experimental time of 60 days. To verify the priming effect on the vermicompost three treatments (in replicas) were performed with E. crassipes: (i) Control - biomass without addition of inorganic compound; (ii) NPK 1.75\%; (iii) NPK treatment 3.5\%: (iv) Glucose $0.25 \mathrm{~g} / \mathrm{L}$ and (v) 
Glucose treatment $0.5 \mathrm{~g} / \mathrm{L}$. The first addition was made after finishing its assembly, being added $100 \mathrm{~mL}$ of the solution in each system and $10 \mathrm{~mL}$ in each mini system. The following applications were of $50 \mathrm{~mL}$ and $10 \mathrm{~mL}$ respectively for system and mini system in the first week, 25 and 10 in the second week and 10 and 5 in the third week.

To monitor the abiotic conditions $(\mathrm{pH}$, electrical conductivity) in the system, weekly samples were taken, in replica, of the vermicompost and monitored the following variables: temperature, humidity, $\mathrm{pH}$ and electrical conductivity (EC). The temperature was obtained by measuring the mercury thermometer. The humidity was obtained by the gravimetric humidity method (Uhland, 1951; Embrapa, 1979), using an oven and precision scale (Bel Engineering brand, model M214Ai). For the pH and EC analyses, an aliquot of vermicompost was separated from the systems to make the aqueous extract (2:8 ratio) with deionized water where the $\mathrm{pH}$ and the EC were measured. The $\mathrm{pH}$ was obtained by potentiometer (pHmeter DIGIMED model DMPH2) and the EC was obtained by potentiometer (Condutivimeter DIGIMED DM3).

Weekly an aliquot (ca. $50 \mathrm{mg}$ ) was separated and removed from the vermicompost in generation, to perform the extraction of humic substances with alkaline extract $(\mathrm{NaOH} 0.5 \mathrm{~mol} / \mathrm{L})$. The extractions were performed until the extracting solution was no longer colored (i.e., transparent). After extraction the alkaline solutions were swept in the following wavelengths $250,254,365,450$ and $665 \mathrm{~nm}$ for the calculations of the concentrations of humic substances and the humification indices $\mathrm{E} 2 / \mathrm{E} 3$ and E4/E6. The E2/E3 ratio is an index that can be related to the quality of the compound. The value of this ratio decreases with the increase of light absorption by chromophore dissolved organic matter, of high molecular mass (Helms et al., 2008) and of aromaticity (Peuravuori \& Pihlaja, 1997; Helms et al., 2008). According to Stevenson (1994), the E4/E6 ratio decreases with the increase in molecular mass and the 
condensation of aromatic constituents and is a humification index. Schnitzer \& Khan (1972) consider that the E4/E6 ratio is inversely proportional to the degree of condensation of humic materials and the residence time of humic materials in the soil.

After the end of vermicomposting in all treatments (ca. 60 days), the remaining biomass (i.e. not consumed by the worms) of E. crassipes was removed from the system and had its masses dried at controlled temperature $\left(50{ }^{\circ} \mathrm{C}\right)$ and then determined gravimetrically in a precision scale (Bel Engineering brand, model M214Ai; precision $0.0001 \mathrm{~g}$ ). To determine the global efficiency (Equation 1) of the vermicomposting the quantification was calculated from the initial and final masses of the E. crassipes. For the descriptions of biomass consumption, a first order model was used (Equation 2). The model parameters $\left(\mathrm{BC}_{\max }\right.$ and $\left.\mathrm{k}\right)$ were obtained from nonlinear regressions; for this purpose, the iterative algorithm of Levemberg-Marquardt (Press et al., 2007) was used.

$$
B C=B C_{\max } \times\left(1-e^{-k t}\right)
$$

in which: $\mathrm{BC}$, accumulated biomass consumption (oxidized biomass + transferred biomass to $\mathrm{E}$. fetida); $\mathrm{BC}_{\max }$, maximum biomass consumption per condition $(\%) ; \mathrm{k}$, consumption coefficient $\left(\right.$ week $\left.^{-1}\right) ; \mathrm{t}$, time (week).

To verify the fertility of the vermicompost in each treatment tests were performed indicating the quality of the compound in an accredited laboratory (Soil Fertility Laboratory - Soil Science Department of ESALQ/USP; Report nº 0017889.1N-O.S.10668). The following tests were performed: Total organic matter obtained by ignition loss (Alcarde, 2009). The organic carbon (\%) was obtained by extraction with dichromate and determination by titulometry. The determination of total $\mathrm{N}(\%)$ was done by sulfuric digestion/Kjeldahl. Total P (\%) was obtained by vanadium ammonium extraction and determination by colorimetry. Total K (\%) was obtained by extraction 
with hydrochloric acid and determination by flame photometry. Total $\mathrm{S}(\%)$ was obtained by extraction by barium chloride and gravimetric method. Total $\mathrm{Ca}(\%)$ and total $\mathrm{Mg}(\%)$ were obtained by extraction with hydrochloric acid and determination by atomic absorption. The $\mathrm{C} / \mathrm{N}$ ratio was determined according to MAPA (2007).

\subsection{Statistical analysis}

Differences in the mean values of variables $\mathrm{pH}, \mathrm{EC}, \mathrm{E} 2 / \mathrm{E} 3, \mathrm{E} 4 / \mathrm{E} 6$ and humic substances between treatments and days of colonization were compared using Two-way ANOVA without replications, and significant differences were considered with $95 \%$ confidence intervals $(\mathrm{p}<0.05)$. Changes of $\mathrm{pH}, \mathrm{EC}, \mathrm{E} 2 / \mathrm{E} 3, \mathrm{E} 4 / \mathrm{E} 6$ and humic substances values along the days of the experiment were analyzed by the Multiple Linear Regression analysis. These variables were used as dependent variables and compared by analysis of variance (ANOVA), with significant differences considered at 95\% confidence intervals $(\mathrm{p}<0.05)$. Spearman rank correlation analysis was used to analyze the associations between the significant variables in humic substance production. The significances of the associations between the variables were analyzed using the correlation coefficients, and the $95 \%$ confidence intervals were considered ( $p$ $<0.05)$.

The initial biomasses and abundances of E. fetida in each treatment were compared with the final values of the experiment using the Wilcoxon test. The values of water hyacinth composting efficiencies between treatments with presence and absence of E. fetida were compared using Two-way ANOVA without replications. Significant differences considered with $95 \%$ confidence intervals $(\mathrm{p}<0.05)$. The relationships of the vermicomposting efficiency of the different treatments with the total period of the experiment and with presence and absence of E. fetida were analyzed through the 
analysis of linear multiple regression. The values of vermicomposting efficiency of the treatments with presence and absence of E. fetida, were considered as dependent variable and the values compared by analysis of variance (ANOVA). Significant differences were considered with $95 \%$ confidence intervals $(\mathrm{p}<0.05)$.

\section{Results and Discussion}

\subsection{Monitoring abiotic variables during vermicomposting}

Humidity and temperature are important variables for the maintenance of $E$. fetida individuals. The ideal temperature for the vermicomposting process is ca. $25^{\circ} \mathrm{C}$, however, worms can withstand conditions at $30^{\circ} \mathrm{C}$ (Anjos, 2015). The metabolic activity, i.e. breathing and growth of earthworms are extremely influenced by temperature (Edwards \& Lofth, 1972), which was observed during vermicomposting temperatures remained below $30^{\circ} \mathrm{C}$ and close to ideal $\left(24 \pm 4^{\circ} \mathrm{C}\right)$. E. fetida requires a substrate with relatively high moisture content, with limits between 60 and $90 \%$ (Dominguez \& Edwards, 2010). The values obtained are within the ideal range, being the mean and standard deviation obtained for each treatment: (i) $56.65 \% \pm 5.23$ (Control); (ii) $69.24 \% \pm 8.37$ (NPK 1.75); (iii) $44.41 \% \pm 8.62$ (NPK 3.5), (iv) $61.73 \pm$ 3.83 (Glucose $0.25 \mathrm{~g} / \mathrm{L}$ ) and (v) $57.48 \pm 6.37$ (Glucose $0.5 \mathrm{~g} / \mathrm{L}$ ). Humidity is directly related to temperature; experiments on the life cycle of E. fetida considered the ideal conditions for the development of this species, $25^{\circ} \mathrm{C}$ and $75 \%$ humidity (Venter \& Reinecke, 1988). The weekly EC variation of the vermicompost shows higher mean values in organic treatments (Table 1).

Table 1: Mean values and variances of the variables measured throughout the process of vermicomposting E. crassipes from treatments enriched with different concentrations of inorganic and organic nutrients \pm Standard Deviation 
Eletric Condutivity $\quad 821.78 \pm 66777.99 \quad 1041.993 \pm 85572.08 \quad 770.58 \pm 24699.42 \quad 1196.49 \pm 60448.31$

\begin{tabular}{|c|c|c|c|c|}
\hline $\mathrm{pH}$ & $8.01 \pm 0.13$ & $7.87 \pm 0.02$ & $8.13 \pm 0.29$ & $7.87 \pm 0.02$ \\
\hline E2/E3 & $3.66 \pm 2.68$ & $2.94 \pm 1.10$ & $3.25 \pm 0.78$ & $1.99 \pm 16.48$ \\
\hline E4/E6 & $2.28 \pm 7.64$ & $9.67 \pm 242.68$ & $7.11 \pm 303.71$ & $1.76 \pm 1.32$ \\
\hline Humic substances & $3.75 \pm 9.26$ & $68.90 \pm 4365.86$ & $13.41 \pm 174.34$ & $46.86 \pm 2210.85$ \\
\hline
\end{tabular}

High EC values contribute to the hypothesis of more fertile compost, given the greater availability of ions in the compost and subsequent use as fertilizer. The solubilization of the protoplasmic contents of aquatic macrophytes releases in the soil high amounts of ions such as K (Park \& Cho, 2003) and metals such as Fe (He et al., 2018). This increase can also occur from the increased availability of soluble salts resulting from the mineralization activity of earthworms and microorganisms that act in their intestines (Karmegam \& Daniel, 2009).

The weekly EC variation shows a significant increase in the treatments NPK $1.75 \%$, Glucose $0.25 \mathrm{~g} / \mathrm{L}$ and Glucose $0.5 \mathrm{~g} / \mathrm{L}$, while in the control and NPK $3.50 \%$ it decreased (Table 2). The increase in EC values was due to the release of ions from the macrophyte biomass, which were incorporated into the humus during the vermicomposting process. However, lower EC values are shown to be better for plant nutrition and growth, as there is a slow release of necessary ions (Ansari \& Rajpersaud, 2012).

Table 2: Changes in vermicomposting variables of E. crassipes over the decomposition period in treatments enriched with different concentrations of inorganic and organic nutrients. Where: coefficient (Coeff.), Standard error (Std. err.) and * (significant differences) 


\begin{tabular}{ccccccc}
\hline Variable & Treatment & Coeff. & Std. err. & T & P & $\mathbf{r}^{2}$ \\
\hline \multirow{4}{*}{ Electric } & Control & -4.80 & 1.29 & -3.75 & $<0.001$ & $0.08^{*}$ \\
conductivity & NPK 1.75 & 2.68 & 1.51 & 1.78 & 0.08 & 0.02 \\
& NPK 3.5 & -3.10 & 0.78 & -3.99 & $<0.001$ & $0.10^{*}$ \\
& Glucose 0.25 & 3.67 & 1.24 & 2.94 & 0.03 & $0.05^{*}$ \\
& Glucose 0.50 & 9.50 & 1.44 & 6.59 & $<0.001$ & $0.23^{*}$ \\
\hline \multirow{5}{*}{ pH } & Control & -0.01 & 0.00 & -8.26 & $<0.001$ & $0.32^{*}$ \\
& NPK 1.75 & 0.001 & 0.00 & 2.69 & 0.01 & $0.04^{*}$ \\
& NPK 3.5 & -0.00 & 0.00 & -1.14 & 0.25 & 0.00 \\
& Glucose 0.25 & 0.00 & 0.00 & 2.69 & 0.01 & $0.04^{*}$ \\
& Glucose 0.50 & 0.00 & 0.00 & 5.28 & $<0.001$ & $0.16^{*}$ \\
\hline \multirow{5}{*}{ E2/E3 } & Control & -0.00 & 0.02 & -0.42 & 0.067 & 0.00 \\
& NPK 1.75 & 0.01 & 0.01 & 0.73 & 0.47 & 0.02 \\
& NPK 3.5 & -0.00 & 0.01 & -0.75 & 0.46 & 0.02 \\
& Glucose 0.25 & 0.04 & 0.05 & 0.85 & 0.40 & 0.03 \\
& Glucose 0.50 & -0.03 & 0.07 & -0.52 & 0.60 & 0.01 \\
\hline \multirow{5}{*}{ E4/E6 } & Control & -0.03 & 0.03 & -1.01 & 0.32 & 0.04 \\
& NPK 1.75 & -0.15 & 0.20 & -0.76 & 0.45 & 0.02 \\
& NPK 3.5 & 0.25 & 0.22 & 1.15 & 0.26 & 0.05 \\
& Glucose 0.25 & 0.00 & 0.01 & 0.44 & 0.65 & 0.00 \\
& Glucose 0.50 & -0.12 & 0.05 & -2.15 & 0.04 & $0.17^{*}$ \\
\hline \multirow{5}{*}{ Humic substances } & Control & -0.05 & 0.03 & -1.30 & 0.20 & 0.07 \\
& NPK 1.75 & -1.08 & 0.82 & -1.30 & 0.20 & 0.07 \\
& NPK 3.5 & 0.14 & 0.16 & 0.87 & 0.39 & 0.03 \\
& Glucose 0.25 & 1.33 & 0.54 & 2.46 & 0.02 & $0.22^{*}$ \\
& Glucose 0.50 & 1.07 & 0.36 & 3.02 & 0.01 & $0.29^{*}$ \\
\hline & & & & & &
\end{tabular}

The $\mathrm{pH}$ temporal analyses of the vermicompost for the different treatments show a variation tending to neutrality (Tables 1 and 2). Pramanik et al. (2007) point out that the decomposition of organic matter implies the formation of ammonium and humic acids, being these two elements responsible for antagonistic effects in the soil. While the presence of humic compounds propitiates the decrease of the $\mathrm{pH}$, the ammonium ions induced its increase; the concomitant presence of the two substances makes the $\mathrm{pH}$ tend to neutrality. The formation of humic substances is characterized by the mineralization of organic matter (Valente, 2009). As for the humification indexes, De Haan (1983) points out that values of E2/E3 close to 4 indicate high humification. The 
results showed that Control and NPK 3.5\% had mean values closer to the indicated value (Table 1). However, these values did not change along vermicomposting experiment days. Low values of the E4/E6 ratio (less than 5) show high quality compounds (Haddad et al., 2015). Other authors (Grayson \& Holden, 2012) suggest that values between 2 and 5 indicate higher humification. To the Control, the Glucose $0.25 \mathrm{~g} / \mathrm{L}$ and Glucose $0.50 \mathrm{~g} / \mathrm{L}$ treatments obtained averages within this range while the total humic substance in the compound enriched with NPK $1.75 \%$ was much higher than the other treatments (Table 1). The glucose-enriched treatments had a significant increase when compared to the other treatments (Table 2). Humic substances consist in the main component of stabilized organic matter and are essential for plant growth (Zandonadi \& Busato, 2012) highlighting the possibility of using the compound for use as fertilizer.

\subsection{Biomass consumption efficiency}

The efficiency of biomass consumption in vermicomposting was not an important indication of feasibility of using macrophyte biomass, however, showed the effectiveness of its use as a sustainable alternative. The kinetics consumption observed by the experiments in the mini systems showed similar patterns in all treatments: an efficiency of less than $50 \%$ in the initial weeks. Until the fourth week of the experiment, the efficiency values remained between $50 \%$ and $75 \%$. It was also possible to observe a sharp increase in biomass consumption of all treatments throughout the experiment, especially at the end, reaching values around $80 \%$ (Figure 1). 


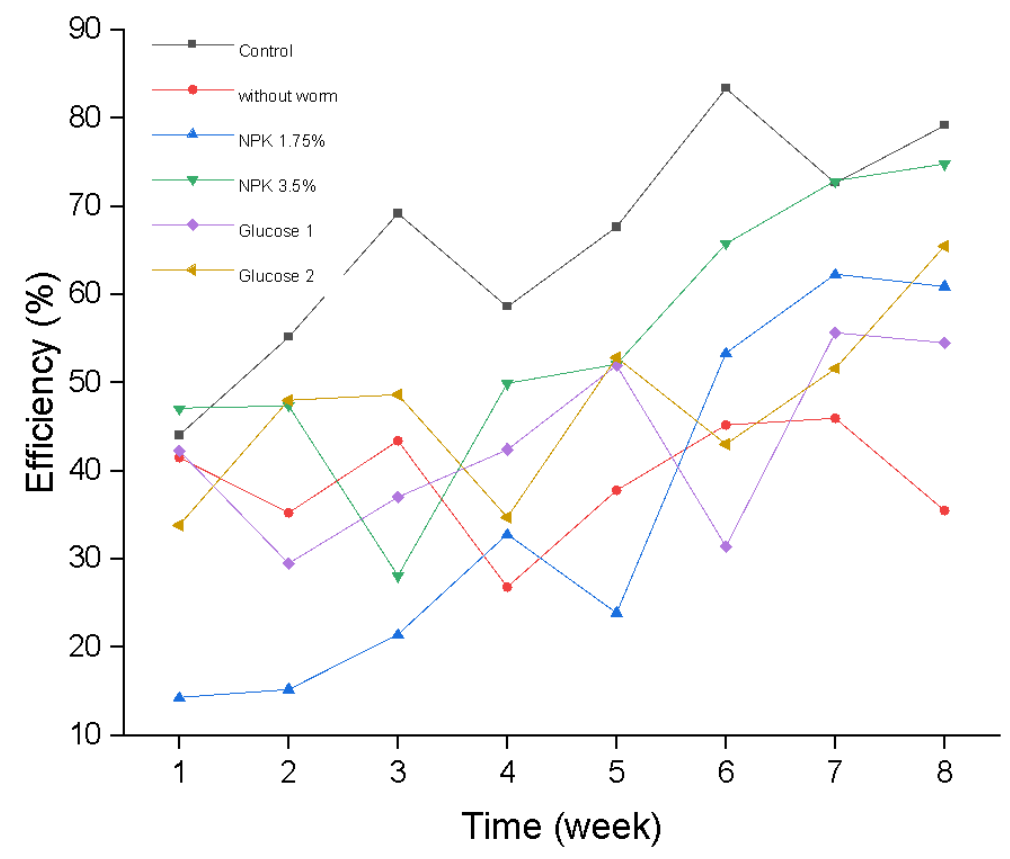

Fig 1: Weekly variation in consumption efficiency of macrophytes in the treatments (Control; NPK $1.75 \%$; NPK 3.5\%; Glucose 0.25g/L and Glucose 0.50g/L).

The treatment without earthworms show an efficiency more stable throw the experiment, varying between $30 \%$ and 50\%. Dominguez and Edwards (2010) highlight that the worms used in vermicomposting have well defined limits of these variables, with the waste being processed more efficiently within a restricted range of favorable chemical and environmental conditions. The degradation resulting from the bioconversion by worms accelerates the mineralization of organic matter, favoring the breakage of structural polysaccharides (such as fibers) increasing the rate of humification (Elvira et al., 1996). The increase in humic acid content and increases in mineral nutrients (e.g. S, N, P and $\mathrm{K}$ ) is related to the degradative processes (decomposition/mineralization) of the organic compound by earthworms (Atiyeh et al., 2001; Cotta et al., 2015). 
The comparative analyses of initial and final biomass and abundance of E. fetida showed that the Control, NPK $1.75 \%$ and $3.50 \%$ treatments concentrations showed significant reduction of biomass at the end of the experiment. The same result was observed for the number of individuals only in the inorganic nutrient treatments (Table $3)$.

Table 3: Results of Wilcox's test analysis between initial and final biomass and number of $E$. fetida individuals in the decomposition process of E. crassipes from treatments enriched with different concentrations of inorganic and organic nutrients

\begin{tabular}{|c|c|c|c|c|c|c|}
\hline & Treatment & Initial & Final & W & $\mathbf{z}$ & p \\
\hline \multirow{12}{*}{ biomass } & & & 1.96 & & & $<0.0001$ \\
\hline & Without worms & $3.11 \pm 0.01$ & \pm 0.10 & 300 & 4.28 & $*$ \\
\hline & & & 1.43 & & & $<0.0001$ \\
\hline & Control & $2.38 \pm 0.33$ & \pm 0.45 & 300 & 4.28 & $*$ \\
\hline & & & 0.44 & & & $<0.0001$ \\
\hline & NPK $1.75 \%$ & $2.51 \pm 0.52$ & \pm 0.22 & 300 & 4.28 & $*$ \\
\hline & & & 1.16 & & & $<0.0001$ \\
\hline & NPK $3.50 \%$ & $2.74 \pm 0.83$ & \pm 0.70 & 295 & 4.14 & $*$ \\
\hline & & & 1.12 & & & \\
\hline & Glucose $0.25 \mathrm{~g} / \mathrm{L}$ & $1.21 \pm 0.12$ & \pm 0.24 & 164 & 0.41 & 0.68 \\
\hline & & & 1.51 & & & \\
\hline & Glucose $0.50 \mathrm{~g} / \mathrm{L}$ & $2.50 \pm 18.29$ & \pm 0.27 & 141 & 0.47 & 0.64 \\
\hline \multirow{10}{*}{$\begin{array}{l}\text { number } \\
\text { of } \\
\text { individual } \\
\mathrm{s}\end{array}$} & & & 2.20 & & & \\
\hline & Control & $2.70 \pm 0.22$ & \pm 1.65 & 101 & 1.78 & 0.07 \\
\hline & & & 1.37 & & & $<0.0001$ \\
\hline & NPK $1.75 \%$ & $3.00 \pm 0.00$ & \pm 1.81 & 168 & 3.68 & $*$ \\
\hline & & & 1.70 & & & $<0.0001$ \\
\hline & NPK $3.50 \%$ & $3.00 \pm 0.00$ & \pm 0.91 & 205 & 3.85 & $*$ \\
\hline & Glucose 0.25 & & 2.67 & & & \\
\hline & $\mathrm{mg} / \mathrm{L}$ & $3.00 \pm 0.00$ & \pm 1.27 & 40 & 1.35 & 0.17 \\
\hline & Glucose 0.50 & & 2.70 & & & \\
\hline & $\mathrm{mg} / \mathrm{L}$ & $3.00 \pm 0.00$ & \pm 0.56 & 10 & 1.84 & 0.07 \\
\hline
\end{tabular}

The comparative analysis between the vermicomposting efficiency treatments with presence and absence of the earthworms, showed that the Control treatment followed by NPK $3.50 \%$ presented significantly higher average efficiencies than the 
other treatments $(\mathrm{F}=16.31, \mathrm{p}<0.001$, Figure 2$)$. The treatments with added organic nutrients showed less variation in average efficiency values.

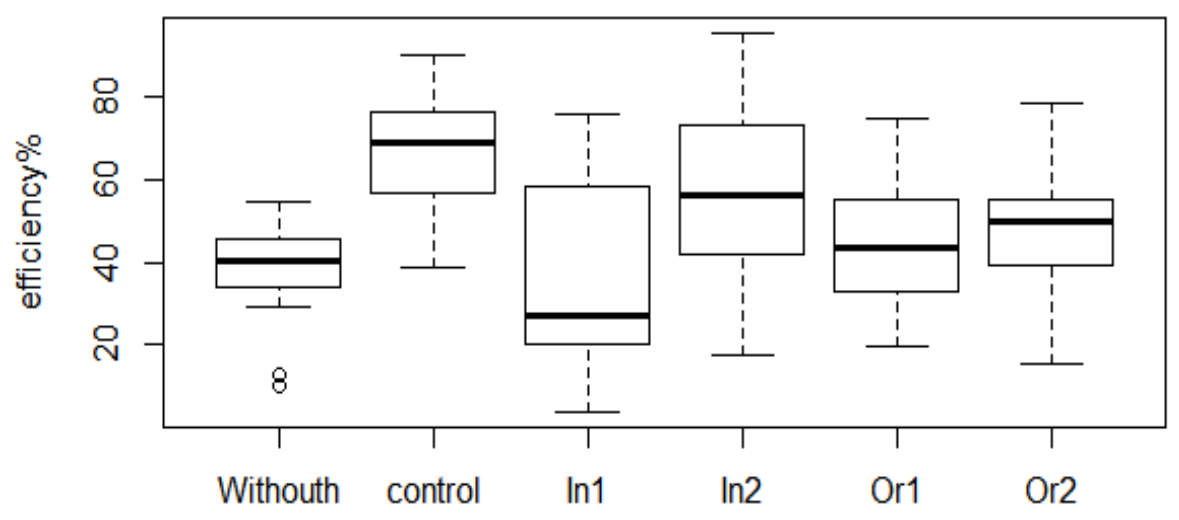

Fig. 2: Average efficiency of vermicomposting of water hyacinth in minisystems with different treatments enriched with different concentrations of inorganic and organic nutrients and absence of earthworms. In1 - NPK 1.75\%, In2 - NPK 3.50\%, Or1 - Glucose 0.25 g/L, Or2 - Glucose 0.50 g/L.

The treatments also differed significantly over the total vermicomposting period $(\mathrm{F}=3.40, \mathrm{p}<0.0001)$. The influence analysis of the variables showed that the efficiency of vermicomposting was significantly positive over the long period (Figure 3) contradicting to the final number of E. fetida (Figure 4). 

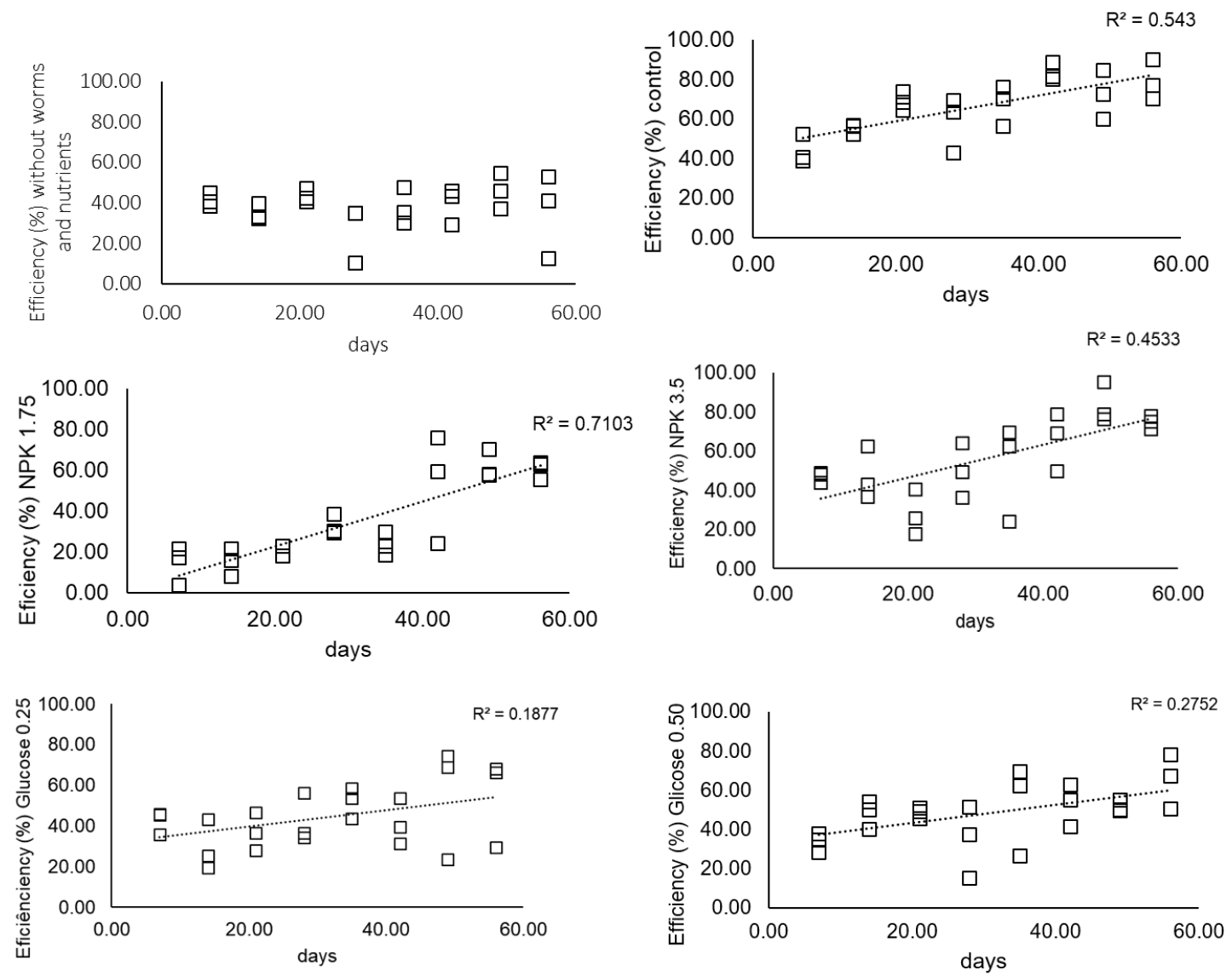

Fig. 3: Influence of the period of days on the formation of humic substances in the vermicomposting process of water hyacinth with different treatments enriched with different concentrations of inorganic and organic nutrients 

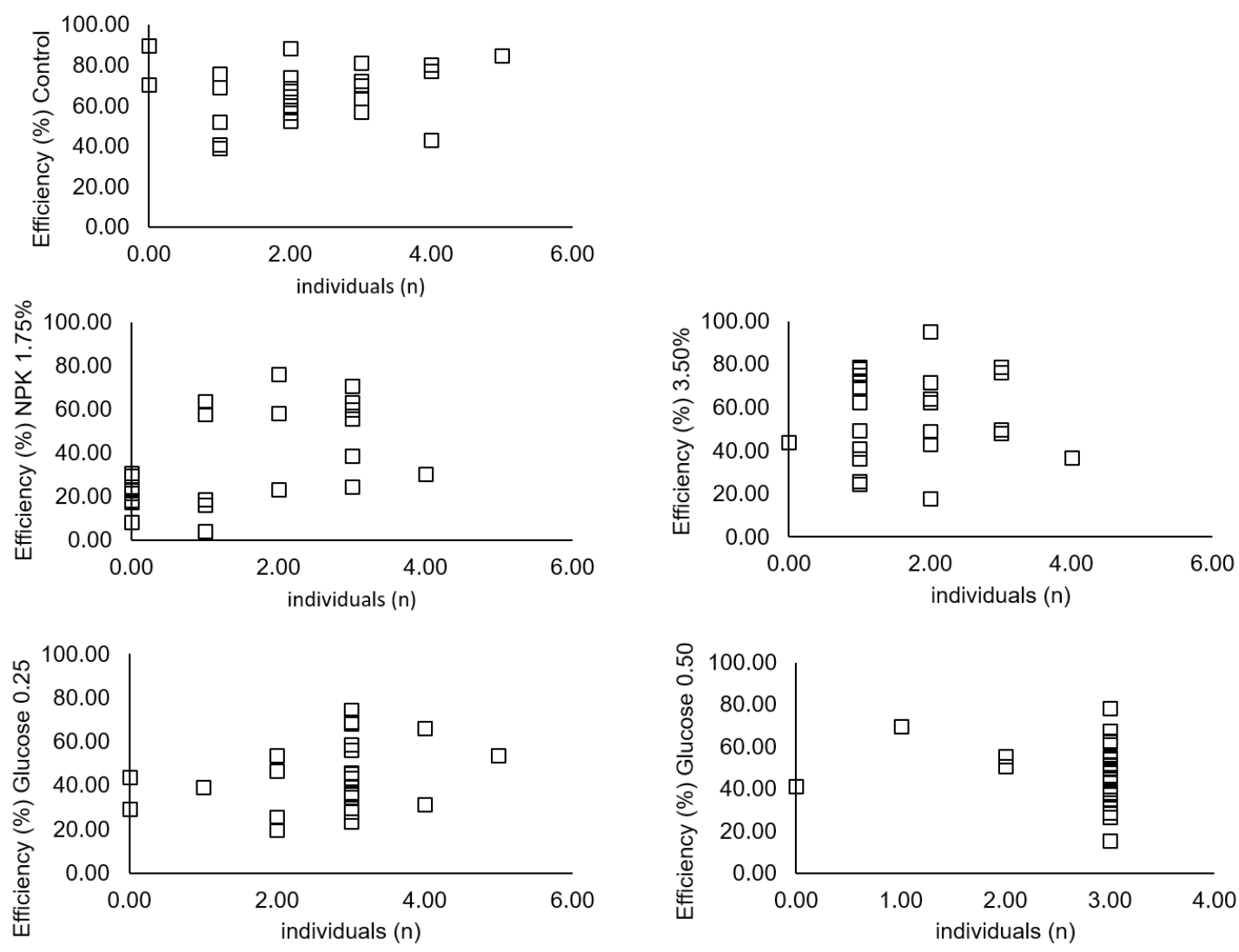

Fig. 4: Influence of the final number of individuals on the formation of humic substances in the vermicomposting process of water hyacinth with different in treatments enriched with different concentrations of inorganic and organic nutrients.

The control and inorganic nutrient treatments showed the highest values of determination coefficients positively influencing the efficiency of water hyacinth composting. We concluded that the influence of $E$. fetida individuals the vermicomposting process of water hyacinth will depend nutrient kind (i.e., organic $\mathrm{X}$ inorganic). We observed this; mainly the inorganic treatments decreasing in biomass and number of earthworms, which present strongest efficiency. Najar \& Khan (2013) indicated that low biomass consumption at the beginning of the experiment may be related to the acclimatization time of the earthworms to a new supply. Parallel to this, 
the change in biomass structure (i.e., decrease in the physical resistance of the biomass) during decomposition may have contributed to increase the consumption, as observed in the final weeks of the experiment, especially to the Glucose $0.50 \mathrm{~g} / \mathrm{L}$ (Figure 1). Najar \& Khan (2013) point out that the chemical composition of the organic resource influences the palatability of worms, which affects biomass consumption. In a review of earthworm food ecology, Curry \& Schmidt (2007) indicated that organic matter intake can be very variable, depending on factors such as favorable environmental conditions for earthworm metabolic activity, nutritional quality of food and palatability. The authors indicate that the exclusive use of water hyacinth biomass of the vermicomposting results in increased mortality of E. fetida individuals. This may be due to the amount of phenois in these plants, which are unpleasant to earthworms. The authors, however, point out that this type of material degrades in a short period. It is suggested making the pre-composting using cattle manure, which consists of a more favorable environment for earthworms. This would occur once that vegetal biomass appears less nutritive and attractive to the earthworms, where animal product waste results in high biomass and favorable to E. fetida life cycle (Vodounnou et al., 2016). Concerning to this, we could infer that probably the efficiency of water hyacinth received the action mainly by development of microbiota along the vermicomposting experiments.

In Table 4 are shown the temporal variations of accumulated consumption and the parameters of the model used (Eq. 2) to describe the kinetics of biomass consumption of E. crassipes. It was found that there was a higher biomass consumption in the high enriched with $3.50 \%$ NPK, with a maximum consumption of $79.7 \%$. However, this condition presented a consumption coefficient $\left(0.31 \mathrm{wk}^{-1}\right)$ lower than the control treatment $\left(0.74 \mathrm{wk}^{-1}\right)$. The intermediate enrichment condition (NPK $1.75 \%$ ) 
showed the lowest consumption yield (65.0\%) and the lowest consumption coefficient $\left(0.20 \mathrm{wk}^{-1}\right)$. The coefficient of determination $\left(\mathrm{r}^{2}\right)$ obtained for the Control treatment was higher (0.94) when compared to the other treatments. Also, for the Control treatment, the accumulated biomass consumption $\left(\mathrm{BC}_{\max }\right)$ was the second highest (Table 4). Glucose $0.50 \mathrm{~g} / \mathrm{L}$ presented the highest consumption coefficient $\left(0.99 \mathrm{wt}^{-1}\right)$ despite having the lowest accumulated consumption among the observed treatments $(47.5 \%)$. The consumption coefficient for the organic treatments were much higher than the others, reaching maximum values $\left(0.95\right.$ and $\left.0.99 \mathrm{wk}^{-1}\right)$.

Table 4: Parameters of the model of biomass consumption of water hyacinth by E. fetida in the tested treatments (Control; NPK 1.75\%; NPK 3.5\%; Glucose 0.25g/L and Glucose 0.5g/L).

\begin{tabular}{|c|c|c|c|}
\hline Treatment & $\mathrm{BC}_{\max }(\%)$ & $\mathrm{k}\left(\mathrm{wk}^{-1}\right)$ & $\mathrm{r}^{2}$ \\
\hline Control & 74.50 & 0.74 & 0.94 \\
\hline NPK $1.75 \%$ & 65.00 & 0.20 & 0.83 \\
\hline NPK 3.50\% & 79.70 & 0.31 & 0.72 \\
\hline Glucose $0.25 \mathrm{~g} / \mathrm{L}$ & 52.50 & 0.95 & 0.83 \\
\hline Glucose $0.50 \mathrm{~g} / \mathrm{L}$ & 47.50 & 0.99 & 0.76 \\
\hline
\end{tabular}

\subsection{Fertility}

The results of the fertility tests for the composts formed by vermicomposting macrophytes are described in Table 5. The treatments had less than the recommended amount of organic matter. For phosphorus all treatments showed values within the lower limit of this range $(0.11 \%$ and $0.12 \%)$. The values of $\mathrm{Mg}$ in the composts produced in vermicomposting were significant, with higher values obtained for the treatments enriched with glucose $(1.61 \%$ and $1.92 \%)$, followed by the Control $(1.75 \%)$ and the treatments enriched with NPK $(1.34 \%$ and $1.05 \%)$. 
Table 5: Results of fertility evaluation (in \%) parameters for vermicomposts using E. crassipes biomass (Control; NPK 1.75\%; NPK 3.50\%; Glucose 0.25g/L and Glucose 0.50 g/L). A recommended values according to Mendes (2007), B - recommended values according to Prezotti \& Guarçoni (2012).

\begin{tabular}{|c|c|c|c|c|c|c|c|}
\hline & Control & $\begin{array}{c}\text { NPK } \\
1.75 \%\end{array}$ & $\begin{array}{c}\text { NPK } \\
3.5 \%\end{array}$ & $\begin{array}{c}\text { Glucose } \\
0.25 \mathrm{~g} / \mathrm{L}\end{array}$ & $\begin{array}{c}\text { Glucose } \\
0.5 \mathrm{~g} / \mathrm{L}\end{array}$ & $\mathrm{A}$ & $\mathrm{B}$ \\
\hline $\begin{array}{c}\text { Total } \\
\text { Organic } \\
\text { Matter }\end{array}$ & 0.95 & 1.88 & 3.11 & 3.30 & 5.16 & 5.00 & - \\
\hline $\begin{array}{c}\text { Organic } \\
\text { Carbon }\end{array}$ & 0.30 & 0.31 & 0.30 & 0.29 & 0.60 & - & - \\
\hline $\begin{array}{c}\text { Total } \\
\text { Nitrogen }\end{array}$ & 0.17 & 0.14 & 0.19 & 0.24 & 0.24 & - & - \\
\hline $\begin{array}{c}\text { Total } \\
\text { Phosphorus }\end{array}$ & 0.09 & 0.11 & 0.12 & 0.13 & 0.13 & $0.10-1.0$ & 1.60 \\
\hline $\begin{array}{c}\text { Total } \\
\text { Potassium }\end{array}$ & 0.16 & 0.17 & 0.19 & 0.19 & 0.27 & $1-3.50$ & 1.50 \\
\hline $\begin{array}{c}\text { Total } \\
\text { Calcium }\end{array}$ & 0.30 & 0.32 & 0.36 & 0.36 & 0.36 & 0.60 & $0.50-3.00$ \\
\hline $\begin{array}{c}\text { Total } \\
\text { Magnesium }\end{array}$ & 1.75 & 1.34 & 1.05 & 1.61 & 1.92 & 6.00 & $0.15-1.00$ \\
\hline $\begin{array}{c}\text { Total } \\
\text { Sulfur }\end{array}$ & 0.03 & 0.05 & 0.07 & 0.05 & 0.05 & $0.10-0.40$ & - \\
\hline
\end{tabular}

The concentration of macronutrients below the recommended limit showed that the formation of a fertile compost by vermicomposting macrophytes, although feasible, lacks some of the attributes necessary for adequate plant nutrition. Other experiments conducted with the association of macrophytes and animal manure (Ansari \& Rajpersaud, 2012; Kannadasan et al., 2013; Sakthika \& Sornalaksmi, 2019) showed much higher values than those obtained for the concentration of macronutrients. The addition of manure also has disadvantages due to the possibility of the presence of fecal coliforms and pathogens, making further use as fertilizer impossible. The enrichment 
with both inorganic (NPK) and organic (glucose) compost caused a subtle increase in the quality of the compost formed. The compost, however, can work as an aggregator to the soil promoting moisture increase and providing greater soil structuring, as well as in association with another fertilizer. The composts enriched with glucose were superior in terms of biomass consumption efficiency, which were $51.5 \%$ and $40.5 \%$ higher than the average of the treatments with NPK. The addition of glucose has the benefits of being easy to obtain and low cost, being a viable alternative for improving production through a sustainable alternative for the use of surplus biomass and transformation into a fertilizer applicable in other local productions. We suggest that future studies test the application of this technique on a large scale.

\section{Conclusion}

Vermicomposting using macrophytes represents a sustainable alternative for the use of this biomass. The addition of both organic and inorganic compounds proved to be adequate for this process, contributing to an increase in efficiency in the consumption of biomass and a subtle improvement in the fertility of the compost formed. The addition of glucose is a low-cost, easily obtained and applicable. Although the addition shows an increase in compost quality, it does not have the necessary requirements for its use as a fertilizer. However, we suggest the use in association with other fertilizers, adding moisture and structuring to the soil. 


\section{Declarations}

- Ethics approval and consent to participate

NOT APPLICABLE

- Consent for publication

NOT APPLICABLE

- Availability of data and materials

The datasets generated and/or analysed during the current study are available in the

"Repositório Institucional UFScar" repository, available in https://repositorio.ufscar.br/.

- Competing interests

The authors declare that they have no competing interests.

- Funding

The authors thank the Conselho Nacional de Desenvolvimento Científico e Tecnológico for the grant and funding of this research and the Fundação de Amparo à Pesquisa do Estado de São Paulo (FAPESP) for the partial funding of this study (2018/00348-0).

- Authors' contributions

All authors contributed to the study conception and design. KK did the material preparation, investigation, collected data and wrote the manuscript. IB and MBCS provided funding, supervised the project, and wrote the manuscript. HHLS contributed to the statistical analyses. All authors read and approved the final manuscript.

- Acknowledgements

NOT APPLICABLE 


\section{References}

1. Alcarde JC (2009) Manual de análise de fertilizantes. Fealq, Piracicaba.

2. Anjos JL, Aquino AM, Schiedeck G (2015) Minhocultura e vermicompostagem: interface com sistemas de produção, meio ambiente e agricultura de base familiar. Embrapa, Brasília.

3. Ansari AA, Rajpersaud J (2012) Physicochemical changes during vermicomposting of water hyacinth (Eichhornia crassipes) and grass clippings. Soil Sci Article ID 984783 doi: 10.5402/2012/984783.

4. Atiyeh RM, Edwards CA, Subler S, Metzger JD (2001) Pig manure vermicompost as a component of a horticultural bedding plant medium: effects on physicochemical properties and plant growth. Biores. Technol 78:11-20 doi: 10.1016/S0960-8524(00)00172-3.

5. Bento L, Marotta H, Enrich-Prast A (2007) O papel das macrófitas aquáticas emersas no ciclo do fósforo em lagos rasos. Oecologia Brasiliensis 11(4):582589 doi: 10.4257/oeco.2007.1104.10.

6. Bernal MP, Alburquerque JA, Moral R (2009) Composting of animal manures and chemical criteria for compost maturity assessment: A review. Bioresour Technol 100(22):5444-5453 doi: 10.1016/j.biortech.2008.11.027.

7. Blagodatskaya EV, Blagodatskya SA, Anderson TH, Kuzyakov Y (2007). Priming effects in Chernozem induced by glucose and $\mathrm{N}$ in relation to microbial growth strategies. Appl. Soil Ecol 37(1-2):95-105 doi: 10.1016/j.apsoil.2007.05.002.

8. Chambers PA, Lacoul P, Murphy KJ, Thomaz SM (2008) Global diversity of aquatic macrophytes in freshwater. Hydrobiology 595(1):9-26 doi: 10.1007/s10750-007-9154-6. 
9. Chapungu L, Mudyazhezha OC, Mudzengi B (2018) Socio-ecological impacts of water hyacinth (Eichhornia crassipes) under dry climatic conditions: the case of Shagashe River in Masvingo, Zimbabwe. J. Environ. Sci. Health A 2(1):3652 doi: 10.26502/jesph.96120027.

10. Chen R, Senbayram M, Blagodatsky S, Myachina O, Dittert K, Lin X, Blagodatskaya E, Kuzyakov Y (2014) Soil C and N availability determine the cottapriming effect: microbial $\mathrm{N}$ mining and stoichiometric decomposition theories. Glob. Change Biol. Bioenergy 20(7):2356-2367 doi:

10.1111/gcb.12475.

11. Cordeiro PF, Goulart FF, Macedo DR, Campos MCS, Castro SR (2020). Modeling of the potential distribution of Eichhornia crassipes on a global scale: risks and threats to water ecosystems. Rev. Ambient. e Agua. 15(2) doi: 10.4136/ambi-agua.2421.

12. Cotta JAO, Carvalho NLC, Brum TS, Rezende MOO (2015) Compostagem versus vermicompostagem: comparação das técnicas utilizando resíduos vegetais, esterco bovino e serragem. Eng. Sanit. e Ambient 20(1):65-78 doi: $10.1590 / \mathrm{S} 1413-41522015020000111864$.

13. Curry JP, Schmidt O (2007). The feeding ecology of earthworms-a review. Pedobiologia 50(6):463-477 doi: 10.1016/j.pedobi.2006.09.001.

14. De Haan H (1983) Use of ultraviolet spectroscopy, gel filtration, pyrolysis/mass spectrometry and numbers of benzoate-metabolizing bacteria in the study of humification and degradation of aquatic organic matter. In: Christman RF, Gjessing ET (ed) Aquatic and Terrestrial Humic Materials. Ann Arbor Science. 
15. Devi C, Khwairakpam M (2020) Bioconversion of Lantana camara by vermicomposting with two different earthworm species in monoculture. Biores. Technol 296 Article 122308 doi: 10.1016/j.biortech.2019.122308.

16. Dominguez J, Edwards CA (2010) Biology and ecology of earthworm species used for vermicomposting. In: Edwards CA, Arancon NQ, Sherman RL (ed) Earthworms, organic wastes, and environmental management. CRC Press, Boca Raton.

17. Edwards CA, Lofty JR (1972) Biology of Earthworms. Chapman and Hall, London.

18. Elvira C, Goicoechea M, Sampedro L, Mato S, Nogales R (1996). Bioconversion of solid paper-pulp mill sludge earthworms. Biores. Technol 57(2):173-177 doi: 10.1016/0960-8524(96)00065-X.

19. Gajalakshmi S, Ramasamy EV, Abbasi SA (2000) Potential of two epigeic and two anecic earthworm species in vermicomposting of water hyacinth. Biores. Technol 76:177-181 doi: 10.1016/S0960-8524(00)00133-4.

20. Gajalakshmi S, Ramasamy, EV, Abbasi SA (2002) Vermicomposting of different forms of water hyacinth by the earthworm Eudrilus eugeniae. Biores. Technol 82(2):165-169 doi: 10.1016/S0960-8524(01)00163-8.

21. Grayson R, Holden J (2012) Continuous measurement of spectrophotometric absorbance in peatland streamwater in northern England: implications for understanding fluvial carbon fluxes. Hydrol. Process 26(1): 27-39 doi: 10.1002/hyp.8106.

22. Haddad G, El-Ali F, Mouneimne AH (2015) Humic matter of compost: determination of humic spectroscopic ratio (E4/E6). Curr. Sci. Int 4(1): 56-72. 
23. Hamer U, Marschner B, Brodowski S, Amelung W (2004) Interactive priming of black carbon and glucose mineralisation. Org. Geochem 35(7): 823-830 doi: 10.1016/j.orggeochem.2004.03.003.

24. He Y, Song N, Jiang HL (2018) Effects of dissolved organic matter leaching from macrophyte litter on black water events in shallow lakes Environ. Sci. Pollut. Res 25(10): 9928-9939 doi: 10.1007/s11356-018-1267-0.

25. Helms JR, Stubbins A, Ritchie JD, Minor EC, Kieber DJ, Mopper K (2008) Absorption spectral slopes and slope ratios as indicators of molecular weight, source, and photobleaching of chromophoric dissolved organic matter. Limnol. Oceanogr 53(3):955-969 doi: 10.4319/lo.2008.53.3.0955.

26. Howard G, Harley K (1997) How do floating aquatic weeds affect wetland conservation and development? How can these effects be minimised? Wetl. Ecol. Manag 5: 215-225 doi: 10.1023/A:1008209207736.

27. Kannadasan N, Natarajan N, Anbusaravanan N, Sekar P, Krishnamoorthy R (2013) Assessment of sustainable vermiconversion of water hyacinth by Eudrilus eugeniae and Eisenia fetida. J. Nat. Appl 5(2):451-454.

28. Kaspari M (2008) Multiple nutrients limit litterfall and decomposition in a tropical forest. Ecol. Lett 11(1):35-43 doi: 10.1111/j.1461-0248.2007.01124.x.

29. Karmegam N, Daniel T (2009) Investigating efficiency of Lampito mauritii (Kinberg) and Perionyx ceylanensis Michaelsen for vermicomposting of different types of organic substrates. Environmentalist 29(3):287-300 doi: 10.1007/s10669-008-9195-Z.

30. Koutika LS, Rainey HJ (2015) A review of the invasive, biological and beneficial characteristics of aquatic species Eichhornia crassipes and Salvinia molesta. Appl. Ecol. Env. Res 13(1):263-275 doi: 10.15666/aeer/1301_263275. 
31. Kurugundla CN, Mathangwane B, Sakuringwa S, Katorah G (2016) Alien invasive aquatic plant species in Botswana: Historical perspective and management. Plant Sci. J 9:1-40 doi: 10.2174/1874294701609010001.

32. Kumari K, Swain AA, Kumar M, Bauddh K (2021) Utilization of Eichhornia crassipes biomass for production of biochar and its feasibility in agroecosystems: a review. J. Environ. Sustain https://doi.org/10.1007/s42398021-00185-7.

33. Laskowski R, Berg B (2005) Litter decomposition: a guide to carbon and nutrient turnover. Academic Press, Amsterdam.

34. Lopes AS (1998) Manual internacional de fertilidade do solo. Potafós, Piracicaba.

35. MAPA (Ministério da Agricultura, Pecuária E Abastecimento) (2007) Manual de métodos analíticos oficiais para fertilizantes minerais, orgânicos, organominerais e corretivos. MAPA, Brasília.

36. Mendes AMS (2007) Introdução a fertilidade do solo. In: Curso de manejo e conservação do solo e da água. Embrapa Semiárido, Barreiras.

37. Najar IA, Khan AB (2013) Management of fresh water weeds (macrophytes) by vermicomposting using Eisenia fetida. Environ. Sci. Pollut. Res 20(9):64066417 doi: 10.1007/s11356-013-1687-9.

38. Najar IA (2017) Vermicomposting of aquatic weeds: a quick review. Plant Sci 4(3):133-136 doi: 10.14719/pst.2017.4.3.311.

39. Park S, Cho KH (2003) Nutrient leaching from leaf litter of emergent macrophyte (Zizania latifolia) and the effects of water temperature on the leaching process. Korean J. Biol. Sci 7(4):289-294 doi: 10.1080/12265071.2003.9647718. 
40. Pavinato PS, Rosolem CA (2008) Disponibilidade de nutrientes no solo: decomposição e liberação de compostos orgânicos de resíduos vegetais Rev. Bras. Cienc. Solo 32(3):911-920 doi: 10.1590/S0100-06832008000300001.

41. Peuravuori J, Pihlaja K (1997) Molecular size distribution and spectroscopic properties of aquatic humic substances. Anal. Chim. Acta 337(2):133-149 doi: 10.1016/S0003-2670(96)00412-6.

42. Pramanik P, Ghosh GK, Ghosal PK, Banik P (2007) Changes in organic-C, N, P and $\mathrm{K}$ and enzyme activities in vermicompost of biodegradable organic wastes under liming and microbial inoculants. Biores. Technol 98: 2485-2494 doi: 10.1016/j.biortech.2006.09.017.

43. Sakthika T, Sornalaksmi V (2019) Nutrients analysis of vermicompost of water hyacinth supplemented with probiotics. Acta Sci. Agric 3(10):10-13 doi: 10.31080/ASAG.2019.03.0637 .

44. Schnitzer M, Khan SU (1972) Humic substances in the environment. Marcel Dekker, Nova York.

45. Stevenson FJ (1994) Humus chemistry. John Wiley \& Sons, Nova York.

46. Suthar S, Pandey B, Gusain R, Gaur RZ, Kumar K (2017) Nutrient changes and biodynamics of Eisenia fetida during vermicomposting of water lettuce (Pistia $s p$.) biomass: a noxious weed of aquatic system. Environ. Sci. Pollut. Res 24(1):199-207 doi: 10.1007/s11356-016-7770-2.

47. Thomaz SM (2002) Fatores ecológicos associados à colonização e ao desenvolvimento de macrófitas aquáticas e desafios de manejo. Planta Daninha 20(SPE):21-33 doi: 10.1590/S0100-83582002000400003. 
48. Tótola MR, Chaer GM (2002) Microrganismos e processos microbiológicos como indicadores da qualidade dos solos, in: Tópicos em ciência do solo. Sociedade Brasileira de Ciência do Solo 195-276.

49. Valente BS, Xavier EG, Morselli TBGA, Jahnke DS, Brum Jr BS, Cabrera BR, Moraes PO, Lopes DCN (2009) Fatores que afetam o desenvolvimento da compostagem de resíduos orgânicos. Arch. Zootec 58(1):59-85 doi: /10.21071/az.v58i224.5074.

50. Venter JM, Reinecke AJ (1988) The life-cycle of the compost worm Eisenia fetida (Oligochaeta). Afr. Zoo 23(3):161-165 doi: 10.1080/02541858.1988.11448096.

51. Villamagna AM, Murphy BR (2010) Ecological and socio-economic impacts of invasive water hyacinth (Eichhornia crassipes): a review. Freshwater Biol 55, 282-298 doi: 10.1111/j.1365-2427.2009.02294.x.

52. Vadounnou DDFV, Kpogue DNS, Tossavi EE, Mennesah GA, Fiogbe ED (2016) Effect of animal waste and vegetable compost on production and growth of earthworm (Eisenia fetida) during vermiculture. Int. j. recycl. org. waste agric 5(1):87-92 https://doi.org/10.1007/s40093-016-0119-5.

53. Zandonadi DB, Busato JG (2012) Vermicompost humic substances: technology for converting pollution into plant growth regulators. International Journal of Environmental Science and Engineering Research 3(2):73-84.

54. Zhang Y, Ma R, Liang Q, Guan B, Loiselle S (2019) Secondary impacts of eutrophication control activities in shallow lakes: Lessons from aquatic macrophyte dynamics in Lake Taihu from 2000 to 2015. Freshw. Sci. 38(4):802817 doi: $10.1086 / 706197$. 



\section{Supplementary Files}

This is a list of supplementary files associated with this preprint. Click to download.

- GraphicalAbstract.jpg 